\title{
ANALISIS FAKTOR RISIKO HIPERTENSI PRIMER PADA LANSIA DI PUSKESMAS DINOYO MALANG
}

\author{
Friska Ardiani Putri ${ }^{1}$, Febri Endra B. S. ${ }^{2}$, Rahayu ${ }^{3}$ \\ Fakultas Kedokteran, Universitas Muhammadiyah Malang \\ J1. Bendungan Sutami 188 A Malang, Kode Pos: 65156 \\ Email : friskaputri.dr@gmail.com
}

\begin{abstract}
ABSTRAK
Analisis faktor risiko hipertensi primer pada lansia di puskesmas Dinoyo Malang. Hipertensi primer merupakan penyakit degeneratif pertama yang banyak diderita oleh lansia. Modifikasi pola hidup dapat menurunkan faktor risiko terjadinya hipertensi primer. Penelitian ini bertujuanmengetahui hubungan antara faktor risiko hipertensi primer dengan timbulnya hipertensi primer pada lansia di puskesmas Dinoyo Malang. Metode yang digunakan adalah Analytical observation dengan pendekatan cross sectional yang dilakukan di Puskesmas Dinoyo Malang. Teknik pengambilan sampel menggunakan purposive random sampling dengan jumlah sampel 103 responden. Data dianalisis secara bivariat dan multivariate dengan regresi logistik. Faktor-faktor yang terbukti sebagai faktor risiko hipertensi adalah konsumsi asin $\mathrm{p}=0,000$; konsumsi zat aditif $\mathrm{p}=0,000$; konsumsi lemak $\mathrm{p}=0,000$; konsumsi kopi $\mathrm{p}=0,000$; merokok $\mathrm{p}=0,000$; stres psikologis $\mathrm{p}=0,000$, jenis kelamin $\mathrm{p}=0,000$, pendidikan $\mathrm{p}=0,000$; olahraga $\mathrm{p}=0,000$; indeks massa tubuh $\mathrm{p}=0,000$; faktor layanan kesehatan $\mathrm{p}=0,526$ tidak signifikan dikarenakan banyak faktor yang mempengaruhi kepatuhan seseorang untuk melakukan pengobatan hipertensi. Hasil uji regresi logistik signifikansi $=0,95(>0,1)$ berarti tidak ada faktor yang paling memengaruhi timbulnya hipertensi primer. Kesimpulannya adalah terdapat hubungan antara faktor risiko dengan timbulnya hipertensi primer pada lansia di puskesmas Dinoyo Malang, namun tidak ada hubungan yang bermakna antara faktor layanan kesehatan dengan hipertensi primer.
\end{abstract}

Kata kunci : Faktor risiko, Hipertensi primer, Lansia

\section{ABSTRACT}

Analysis Risk Factors of Esential Hypertension at Elderly in Puskesmas Dinoyo Malang. Esential bypertension is the first degeneratif disease that suffered by elderly. Life style modification can lower the risk of esential bypertension. The aimtof this experiment is to know the correlation between the risk factor of bypertension and the incidence of esential bypertension at elderly in Puskesmas Dinoyo Malang. The methods was observational with cross sectional study. Total Repondents were 103 people. Sample were taken by purposive random sampling. Analysis of the data was bivariate and multivariate with logistic regression.

The results are factors proven as risk factors of bypertension were salt consumption $p=0,000$; additives consumption $p=0,000$; fat consumption $p=0,000$; coffe consumption $p=0,000$; smoking $p=0,000 ;$ pyychological stress $p=0,000$, gender $p=0,000$, education $p=0,000$; exercise $p=0,000$; body mass index $p=0,000$; healthcare service $p=0,526$ unsignificant, many factors can affect the compliance of someone to commited bypertension treatments. Result significancy of logistic regression $=0,95(>0,1)$ it means there is no factor that become the most predisposed factor. The conclusion is there is correlation between risk factor of bypertension with the incidence of esential bypertension at elderly in Puskesmas Dinoyo Malang, exclude healthcare service.

Keyword : Risk factors, Esential Hypertension, Elderly 


\section{PENDAHULUAN}

Keberhasilan pembangunan negara-negara di dunia dalam segala bidang termasuk kesehatan akan memperbaiki kualitas hidup dan kesehatan masyarakat sehingga berdampak pada peningkatan usia harapan hidup serta peningkatan jumlah penduduk lansia dari tahun ke tahun (DEPKES, 2014). Hal ini dapat dilihat dalam data Sensus Penduduk Indonesia 2010, yang menunjukkan jumlah penduduk usia lanjut sebanyak $9,77 \%$ dimana jumlah ini mengalami peningkatan jika dibandingkan dengan hasil sensus penduduk Indonesia pada tahun 2000 dengan proporsi penduduk usia lanjut sebesar $7,18 \%$. Selain itu, menurut data yang diperoleh dari Badan Pusat Statistik pada tahun 2012, perkembangan proporsi penduduk lansia di Indonesia sejak tahun 1980 sampai 2010 terus mengalami peningkatan dan diproyeksikan pada tahun 2020 akan terus mengalami peningkatan hingga mencapai angka 11,3\%.

Diantara sepuluh jenis penyakit yang banyak diderita oleh lansia seperti artritis, stroke, penyakit paru obstruktif kronik, diabetes melitus, hipertensi ,kanker, penyakit jantung koroner,batu ginjal, gagal jantung, dan gagal ginjal, hipertensi menempati urutan pertama penyakit degeneratif yang banyak diderita oleh lansia dengan prevalensi $45.9 \%$ pada usia 55-64 tahun, 57,6 \% pada usia 65-74 tahun, dan 63,8 \% pada usia 75 ke atas. (DEPKES, 2014)

Faktor-faktor yang mempengaruhi terjadinya hipertensi itu sendiri dibagi menjadi dua kelompok besar yaitu faktor yang melekat atau tidak dapat diubah seperti jenis kelamin, umur, genetik dan faktor yang dapat diubah seperti pola makan, kebiasaan olah raga dan lain-lain. Untuk terjadinya hipertensi perlu peran faktor risiko tersebut secara bersama-sama (common underlying risk factor), dengan kata lain satu faktor risiko saja belum cukup menyebabkan timbulnya hipertensi (DEPKES, 2006).

Data yang diperoleh dari Dinas Kesehatan Kota Malang pada tahun 2014, hipertensi menjadi penyakit terbanyak nomor dua di Kota Malang, dengan jumlah penderita sebesar 58.046 jiwa. Kota malang sendiri terdiri dari 15 puskesmas. Satu diantaranya adalah Puskesmas Dinoyo, Puskesmas Dinoyo sendiri memiliki jumlah kunjungan pasien yang cukup banyak didukung dengan adanya sumber daya manusia yang cukup, lokasi berada dipusat kota dan merupakan Puskesmas rawat jalan. Berdasarkan data yang diperoleh dari Puskesmas Dinoyo menunjukkan adanya kunjungan lansia dengan diagnosis hipertensi primer pada periode bulan September 2015 hingga Maret 2016 sebanyak 377 lansia.

Hal ini mendorong peneliti untuk melakukan penelitian lebih lanjut mengenai analisis faktor resiko hipertensi primer pada lansia di Kota Malang dengan pengambilan sampel di Puskesmas Dinoyo.

\section{METODE PENELITIAN}

Penelitian ini termasuk dalam rancangan epidemiologiAnalytic observational dengan desain study cross sectional .Penelitian ini menganalisis faktor risiko kejadian hipertensi primer pada lansia di kota Malang pada tahun 2016.

. Dilakukan di Puskesmas Dinoyo Malang. Populasi adalah lansia yang di diagnosis hipertensi di Puskesmas Dinoyo Malang berdasarkan data sekunder rekam medis periode September 2015 Maret 2016 dan sampel yang diambil adalah sebanyak 103 responden

Teknik pengambilan sampel yang digunakan pada penelitian ini adalah purpossive sampling dengan menentukan jumlah responden kasus yang memenuhi kriteria inklusi. Kriteria inklusi yang dimaksudkan dalam penelitianini antara lain, (1)Subyek penelitian yang menderita hipertensi(2)Subyek penelitian yang bersedia mengisi inform consent (3)Berusia e" 60 tahun. Sedangkan kriteria eksklusi meliputi (1) Responden meninggal atau tidak ditemukan (2)Responden memiliki kemunduran daya ingat (3)Responden memilki gangguan pendengaran dan gangguan bicara (4) Pasien hipertensi disertai dengan penyakit pada organ lain, seperti kardiovaskular, ginjal dan kerusakan organ lainnya.

Variabel dependeen dalam penelitian ini adalah kejadian hipertensi pada lansia. Sedagkan variabel indpenden diantaranya riwayat pendidikan, jenis kelamin, merokok, konsumsi makanan asin,konsumsi makanan berbahan zat aditif, konsumsi makanan berlemak, konsumsi kopi, olahraga, obesitas, pelayanan kesehatan dan stres psikologis. 
Pengambilan data dilakukan dengan cara pengambilan data secara primer yaitu menggunakan kuesioner dengan wawancara serta pengambilan data sekunder berupa rekam medis periode September 2015 - Maret 2016.

Setelah pengambilan data, dilakukan rekapitulasi data dan diolah menggunakan SPSS dengan uji statistik menggunakan Lambda dan Regresi Logistik.

\section{HASIL PENELITIAN}

Distribusi responden pada pasien hipertensi pada penelitian ini dibagi dalam beberapa kategori. Kategori tersebut adalah kebiasaan konsumsi asin, kebiasaan konsumsi makanan berbahan zat aditif, kebiasaan konsumsi makanan berlemak,kebiasaan konsumsi kopi,olahraga, kebiasaan merokok, faktor stress, riwayat pendidikan, frekuensi kunjungan posyandu lansia, indeks massa tubuh, dan jenis kelamin.

Sebagian besar responden berjenis kelamin perempuan $(58,30 \%)$. Kemudian riwayat pendidikan, sebagian besar responden memiliki riwayat pendidikan tamat Sekolah Dasar (30,09\%). Distribusi responden berdasarkan pola makan, responden paling banyak $(29,10 \%)$ memiliki kebiasaan selalu mengonsumsi makanan asin. Sebagian besar responden mengaku sering mengkonsumsi makanan berbahan zat aditif $(41,70 \%)$. Distribusi responden yang memiliki kebiasaan mengonsumsi makanan berlemak sebagian besar (28,15\%) memiliki kebiasaan selalu mengonsumsi makanan berlemak. Untuk distribusi rsponden berdasarkan kebiasaan konsumsi kopi sebagaian besar mengaku memiliki kebiasaan mengkonsumsi kopi dengan kategori sering $(30,10 \%)$. Distribusi responden berdasarkan indeks massa tubuh ,sebagian besar masuk ke dalam kategori gemuk (36,90\%).

Pola perilaku responden yang diamati berdasarkan kebiasaan merokok, sebagian besar $(57,20 \%)$ tidak merokok, berdasarkan kebiasaan olahraga sebagian besar $(37,86 \%)$ menyatakan bahwa dirinya tidak pernah melakukan kebiasaan olahraga, sedangkan frekuensi kunjungan ke posyandu lansia, sebagian besar responden $(38,80 \%)$ masuk dalam kategori kadang-kadang. Sedangkan distribusi reponden berdasarkan rtingkat stress, sebagian besar responden masuk dalam kategori ringan sebesar $(27,18 \%)$

Hasil uji lambda didapatkan satu variabel tidak signifikan. Variabel tersebut adalah variabel frekuensi kunjungan lansia ke layanan kesehatan. Koefisien korelatif terbesar adalah variabel stress sebesar 1,000 dan terkecil adalah variabel kebiasaan merokok (dari data yang signifikan).

\begin{tabular}{|c|c|c|}
\hline Variabel & $\begin{array}{c}\text { Signifikansi } \\
(\mathrm{p})\end{array}$ & $\begin{array}{c}\text { Koefisien } \\
\text { Korelasi (r) }\end{array}$ \\
\hline Konsumsi asin & 0,000 & 0,698 \\
\hline Konsumsi zat aditif & 0,000 & 0,930 \\
\hline Indeks Massa Tubuh & 0,000 & 0,767 \\
\hline Jenis kelamin & 0,000 & 0,721 \\
\hline Kebias aan minum kopi & 0,000 & 0,907 \\
\hline $\begin{array}{c}\text { Kebiasaan merokok } \\
\text { Konsumsi makanan } \\
\text { berlemak }\end{array}$ & 0,000 & 0,005 \\
\hline Pendidikan & 0,000 & 0,098 \\
\hline Stres & 0,000 & 1,000 \\
\hline Layanan kes ehatan & 0,526 & 0,47 \\
\hline Olahraga & 0,000 & 0,884 \\
\hline
\end{tabular}

(Data Sekunder, 2017)

Uji regresi logistik menunjukkan bahwa semua faktor memiliki pengaruh terhadap faktor yang lain, sehingga tidak dapat ditentukan faktor yang paling berpengaruh terhadap timbulnya dislipidemia. Hal ini didukung dengan nilai OR sebesar 1,395.

\begin{tabular}{|c|c|c|c|c|c|c|}
\hline & B & S.E & Wald & Df & Sig. & $\operatorname{Exp(B)}$ \\
\hline Constant &, 333 & 0,200 & 2,780 & 1 & 0,95 & 1,395 \\
\hline
\end{tabular}

(Data Sekunder, 2017) 


\section{PEMBAHASAN}

Hasil penelitian menunjukkan bahwa kebiasaan konsumsi makanan asin memiliki pengaruh terhadap keadaaan hipertensi primer $(p=0,000 ; r=0,698)$. Hal ini sesuai dengan suatu penelitian yang menyatakan bahwa semakin tinggi asupan garam maka akan semakin tinggi tekanan darah dan jugasemakin kuat denyut jantungnya ( $\mathrm{Ha}$ ,2014).

Kebiasaan mengonsumsi makanan asin berpengaruh pada penelitian ini dimungkinkan karena teori yang menyatkan bahwa dengan asuoan garamm yang berlebih akan mengaktifkan sistem Renin Angiotensin Aldosteron System (RAAS). Sistem ini yag membuat berbagai aktivitas pembuluh darah terjadi. Aktivitas tersebut adalah kerusakan endotelium pada dinding pembuluh darah. Hal inilah yang menyebabkan terjadinya peningkatan tekanan darah dan curah jantung (Dallal, 2012)

Hasil penelitian menunjukkan bahwa kebiasaan konsumsi makanan berbahan zat aditif memiliki pengaruh terhadap timbulnya hipertensi primer $(p=0,000 ; r=0,930)$. Penelitian ini sejalan dengan penelitian yang menyebutkan bahwa makanan berbahan zat aditif seperti western fast food mengandung penyeddap rasa berupa monosodium glutamat (MSG). MSG ditambahakan untuk membangkitkan cita rasa dengan menstimulasi reseptor citarasa di sel pengecap, bila digunakan secara berlebihan dan dalam jangka waktu yang lama akan mengakibatkan gangguan kesehatan. MSG dan bahan aditif lainnya mengandung kadar natrium yang tinggi yaitu mengandung 12,3\% natrium yang apabila disetarakan, dalam 1 sendok teh MSG mengandung $500 \mathrm{mg}$ natrium. Natrium ini yang mengakibatkan volume plasma darah dan curah jantung meningkat yang menyebabkan tekanan darah meningkat (Eka,2010).

Seperti halnya konsumsi asin, konsumsi makanan dengan kandungan zat aditif berupa natrium ini akan mengaktifkan sistem reninangiotensin aldosteron (RAAS). Sistem ini yang membuat berbagai aktivitas pembuluh darah terjadi. Aktivitas tersebut adalah kerusakan endotelium pada dinding arteri yang menyebabkan vasokonstriksi pembuluh darah dan menyebabkan terjadinya peningkatan tekanan darah dan curah jantung (Dalal, 2012)
Hasil penelitian menunjukkan bahwa kebiasaan konsumsi makanan berlemak memiliki pengaruh yang sangat kuat terhadap timbulnya hipertensi $\operatorname{primer}(\mathrm{p}=0,000 ; \mathrm{r}=0,884)$. Hal ini sesuai dengan penelitian yang menyebutkan bahwa konsumsi makanan berlemak memiliki hubungan yang signifikan denganterjadinya hipertensi dengankebiasaan makanan berlemak (Mahmudah,2015).

Kebiasaan konsumsi makanan berlemak berpengaruh dalam terjadinya hipertensi primer ini dimungkinkan karena makanan berlemak dapat meningkatkan kadar LDL bersumber dari makanan akan menyebabkan timbulnya plak pada pembuluh darah. Semakin lama kuantitas agregat LDL pada dinding arteri akan meningkatakan stimulus proses inflamasi dan respon apoptosis. Keadaan ini yang menyebabkan dinding pembuluh darah rusak dan membuat peningkatan tekanan darah (Kumbla, 2016).

Hasil penelitian menunjukkan bahwa kebiasaan konsumsi kopi memiliki pengaruh terhadap kejadian hipertensi primer $(p=0,000 ; r=0,907)$. Hal ini sesuai dengan sebuah penelitian yang menyatakan kebiasaan konsumsi kafein dapat mempengaruhi terjadinya hipertensi primer ,kafein meningkatkan tekanan darah sistolik sebesar 17\% dan juga meningkatkan denyut jantung. Pada penelitian disebutkan bahwa peningkatan signifikan pada tekanan darah sistolik dengan ratarata dari $115 \mathrm{mmHg}$ menjadi $130 \mathrm{mmHg}$ (Geethavani, 2014).

Kebiasaan mengonsumsi kopi ini berpengaruh pada penelitian ini dimungkinkan karena sesuai dengan teori yang menyatakan bahwa kafein menstimulasi kekakuan aorta.Hal ini terjadi karena kafein meningkatkan produksi dari angiotensin II dan katekolamin yang menginhibisi aktivitas reseptor adenosine A2a di otot polos pembuluh darah. Hal ini dapat terjadi oleh karena kafein memiliki sifat mirip dengan aktivitas ganglion simpathetik noradrenalinn yang berkontribusi terhadap peningkatan aktivitas pembuluh darah (Geethavani, 2014).

Hasil penelitian menunjukkan bahwa kebiasaan olahraga memiliki pengaruhterhadap kejadian hipertensi primer $(\mathrm{p}=0,000 ; \mathrm{r}=0,884)$. Aktivitas fisik yang teratur dapat menurunkan risiko aterosklerosis yang merupakan salah satu penyebab hipertensi. aktivitas fisik yang teratur berupa olahraga dapat menurunkan tekanan sistolik sebesar 10 
$\mathrm{mmHg}$, dan tekanan diastolik sebesar 7,5 $\mathrm{mmHg}$ (Rahayu, 2012).

Kebiasaan olahraga dalam penelitian ini berpengaruh terhadap terjadinya hipertensi dimungkinkan karena olahraga secara teratur dapat menurunkan tahanan perifer yang akan menurunkan tekanan darah untuk hipertensi dan melatih otot jantung sehingga menjadi terbiasa apabila jantung harus melakukan pekerjaan yang lebih berat karena adanya kondisi tertentu.olahraga juga dikaitkan dengan peran obesitas pada hipertensi. Kurang melakukan olahraga akan meningkatkan kemungkinan timbulnya obesitas. Orang yang tidak aktif akan cenderung mempunyai frekuensi denyut jantung yang lebih tinggi sehingga otot jantungnya harus bekerja lebih keras pada setiap kontraksi. Makin keras dan sering otot jantung harus memompa, makin besar tekanan yang dibebankan pada arteri (Suparto,2010).

Hasil penelitian menunjukkan bahwa kebiasaan merokok memiliki pengaruh yang kuat terhadap timbulnya hipertensi $(\mathrm{p}=0,000 ; \mathrm{r}=$ $0,605)$. Rokok mengandung zat-zat berbahaya yang berkontribusi sebagai pemicu dan mempercepat terjadinya aterosklerosis yang memicu agregasi platelet sehingga meningkatkan kebutuhan oksigen miokard, kondisi ini menyebabkan peningkatan denyut jantung dan tekanan darah. Kegiatan merokok yang berlebihan meningkatkan resiko terjadinya hipertensi dan penyakit kardiovaskuler (Black \& Hawks, 2009).

Hasil menunjukkan bahwa faktor stress memiliki pengaruh yang kuat terhadap timbulnya hipertensi primer $(p=0,000 ; r=1,000)$. Hal ini sejalan dengan sebuah penelitian yang menyebutkan bahwa sekitar 38,45\% dari sampel penelitian dilaporkan dalam keadaan stres akan memiliki tekanan darah yang lebih tinggi dari pada sampel yang tidak mengalami stres. Hal ini menunjukkan bahwa faktor psikologis juga memengaruhi tekanan darah. Stres psikologis berkontribusi sebanyak 9\% pada risiko terjadinya hipertensi. Penelitian pada 52 negara menyebutkan bahwa terdapat hubungan yang kuat antara infark mokard dengan keadaan stres yang terjadi di rumah, stres finansial, dan stres terhadap permasalahan hidup lainnya $(H u$ et al, 2015).

Stres dapat mempengaruhi timbulnya hipertensi sesuai dengan teori yang menyebutkan bahwa kondisi stres meningkatkan aktivitas saraf simpatis yang kemudian meningkatkan tekanan darah secara bertahap. Stres dapat merangsang kelenjar anak ginjal untuk melepaskan hormon adrenalin dan memacu jantung berdenyut lebih cepat serta lebh kuat, artinya semakin berat kondisi stres seseorang maka semakin tinggi pula tekanan darahnya.

Stres juga dimungkinkan menjadi salah satu faktor risiko yang sangat kuat dan bisa memengaruhi atau memunculkan faktor risiko yang lain berupa perubahan perilaku ataupun perubahan pola makan.

Hasil penelitian menunjukkan bahwa faktor pendidikan memiliki pengaruh yang kuat terhadap timbulnya hipertensi ( $p=0,000 ; r=0,698)$.

Tingkat pendidikan secara tidak langsung juga mempengaruhi tekanan darah. Tingkat pendidikan berpengaruh terhadap gaya hidup yaitu kebiasaan merokok, kebiasaan minum alkohol, dan kebiasaan melakukan aktivitas fisik seperti olahraga. Hasil Riskesdas tahun 2013 dalam Badan Penelitian dan Pengembangan Kesehatan (2013) menyatakan bahwa penyakit hipertensi (tekanan darah tinggi) cenderung tinggi pada pendidikan rendah dan menurun sesuai dengan peningkatan pendidikan. Tingginya risiko terkena hipertensi pada pendidikan yang rendah, kemungkinan disebabkan karena kurangnya pengetahuan pada seseorang yang berpendidikan rendah terhadap kesehatan dan sulit atau lambat menerima informasi (penyuluhan) yang diberikan oleh petugas sehingga berdampak pada perilaku/pola hidup sehat (Anggara dan Prayitno, 2013 ).

Hasil penelitian menunjukkan bahwa faktor tingkat pelayanan kesehatan tidak memiliki pengaruh terhadap keadaan hipertensi derajat $2(\mathrm{p}=0,526$; $r=0,47)$. Hal ini sesuai dengan penelitian yang dilakukan Libri (2016) yang menyatakan bahwa tidak ada hubungan yang signifikan antara tingkat pengetahuan tentang hipertensi yang diberikan pelayanan kesahatan terhadap derajat hipertensi. Penelitian ini menyebutkan bahwa variabel ini tidak secara langsung memengaruhi tekanan darah.

Faktor tingkat pelayanan kesehatan tidak berpengaruh dalam penelitian ini dimungkinkan karena meskipun seseorang mendapat pengetahuan dari pelayanan kesehatan tentang hipertensi, namun banyak faktor yang memengaruhi kepatuhan seseorang untuk melakukan pengobatan hipertensi. Faktor-faktor tersebut antara lain faktor status 
ekonomi, pengalaman penggunaan obat terhadap efek samping obat, jarak tempat pelayanan kesehatan (Libri, 2016).

Hasil penelitian menunjukkan bahwa indeks massa tubuhmemiliki pengaruh terhadap keadaan hipertensi derajat $2(p=0,000 ; r=0,767)$. Hal ini sesuai dengan penelitian yang dilakukan Zhang (2017) yang menyatakan bahwa seseorang dengan status gizi obesitas memiliki tekanan darah sistole ( $\mathrm{p}$ $<0,05)$ dan diastole $(\mathrm{p}<0,01)$ lebih tinggi. Makanan yang tidak sehat bisa meningkatkan resiko obesitas. Pengukuran antropometri seperti BMI (Body Mass Index), WC (Waist Circumference), WHR (Waist - Hip Ratio), WHtR (Weist - to - beight ratio) berhubungan dengan peningkatan tekanan darah.

Obesitas memiliki pengaruh terhadap hipertensi sesuai dengan teori yang menyebutkan bahwa kelebihan berat badan sama kaitannya dengan pola makan yang tidak seimbang yaitu konsumsi energi tinggi yang akan meningkatkan toleransi glukosa dan insulin plasma yang akan menyebabkan terjadinya reabsorbsi natrium dan peningkatan tekanan darah secara terus menerus (Hull, 2001).

Hasil penelitian menunjukkan bahwa jenis kelamin memiliki pengaruh terhadap keadaan hipertensi derajat $2(p=0,000 ; r=0,721)$. Hal ini sejalan dengan sebuah penelitian Doumas (2013) yang menyatakan bahwa tekanan darah akan lebih tinggi pada kelompok wanita dibandingkan dengan kelompok pria yang dimungkin karena pengaruh dari hormonal. Penelitian lain juga menyebutkan bahwa kontrasepsi merupakan faktor risiko terjadinya hipertensi. Pada penelitian disebutkan bahwa wanita yang menggunakan kontrasepsi pil berisiko 1,4 kali untuk mengalami hipertensi dibandingkan dengan wanita yang tidak menggunakan kontrasepsi (Pangaribuan, 2015).

Jenis kelamin berpengaruh pada penelitian ini dimungkinkan karena teori yang menyebutkan bahwa adanya hormon estrogen dan progesteron akan meningkatkan respon presor angiotensin II dengan melibatkan jalur RAAS. Jalur ini yang membuat tekanan darah seseorang menjadi meningkat (Pangaribuan, 2015).

Pada data hasil uji statistik multivariat yang menggunakan regresi logistik menunjukkan bahwa nilai signifikansi lebih besar dari alpha. Sehingga, pada uji statistik multivariat ini tidak dapat diambil kesimpulan variabel mana yang paling berpengaruh terhadap timbulnya hipertensi primer pada lansia. Hal ini dikarenakan setiap variabel independen dengan hubungan bermakna pada uji bivariat saling memengaruhi untuk terjadinya hipertensi primer pada lansia. Hal ini dibuktikan dengan hasill uji statistik bivariat dengan signifikansi yang kuat namun dilakukan uji secara bersamaan pada uji multivariat, dihasilkan data yang tidak signifikan.

Maka dapat disimpulkan tidak ada variabel bebas yang terdiri dari kebiasaan konsumsi makanan asin,konsumsi makan dengan kandungan zat aditif, indeks massa tubuh (obesitas), jenis kelamin, kebiasaan konsumsi kopi, kebiasaan merokok, kebiasaan konsumsi makanan berlemak, riwayat pendidikan, tingkat stress psikologis, dan kebiasaan olahraga yang paling berpengaruh terhadap timbulnya hipertensi primer pada lansia di Puskesmas Dinoyo Malang.

Berdasarkan data OR (Odd Ratio) pada uji regresi logistik bernilai 1,395. Dapat dikatakan bahwa apabila muncul seluruh variabel bebas pada satu orang, kemungkinan orang tersebut menderita hipertensi primer adalah sebesar 1,395.

\section{KESIMPULAN}

Berdasarkan penelitian dapat disimpulkan: (1)Terdapat hubungan antara faktor risiko yang terdiri dari riwayat pendidikan, jenis kelamin, kebiasaan konsumsi makanan asin,konsumsi makan dengan kandungan zat aditif, kebiasaan konsumsi kopi, kebiasaan konsumsi makanan berlemak, indeks massa tubuh, kebiasaan merokok, kebiasaan olahraga, dan tingkat stres psikologis, dengan timbulnya hipertensi primer pada lansia di Puskesmas Dinoyo Kota Malang, namun tidak ada hubungan yang bermakna antara faktor layanan kesehatan terhadap timbulnya hipertensi primer pada lansia. (2) Semua variabel saling mempengaruhi sehingga dapat dikatakan tidak ada variabel bebas yang paling berpengaruh terhadap munculnya hipertensi primer pada lansia di Puskesmas Dinoyo Kota Malang.

\section{DAFTAR PUSTAKA}

Adriaansz Patricia,2016, Hubungan Konsumsi Makanan dengan Kejadian Hipertensi pada Lansia di Puskesmas Ranomuut Kota Manado, Jurnal Unsrat,Vol 4.No 1 
Aripin,2015, Pengaruh Aktivitas Fisik, Merokok Dan Riwayat Penyakit Dasar Terhadap Terjadinya Hipertensi Di Puskesmas Sempu Kabupaten Banyuwangi Tahun 2015,Program Magister, Universitas Udayana, Denpasar.

Bahri Samsul,2016,Hubungan Antara Konsumsi Rokok Elektrik dan Kejadian Hipertensi (Studi Pada Kelompok Burung Kenari Di Sawojajajr Malang), Thesis, University of Mubammadiyah Malang.

Balitbang Kemenkes RI, 2013, Riset Kesehatan Dasar; RISKESDAS, Jakarta: Balitbang Kemenkes RI.

Chandra Irwani Mohani, 2015, Hipertensi Primer, In :Siti Setiati, Idrus Alwi, Aru W Sudoyo (Eds),Buku Ajar Ilmu Penyakit Dalam, 2 Edn, Interna Publishing, Jakarta,pp 22862295.

Dalal , 2012, Lipitension: Interplay between Dyslipidemia and Hypertension, Indian Journal of Endocrinology and Metabolism, India

Daugherty. 2011, Age Dependant Gender Differences in Hypertension Management

Davey Patrick,2014,At A Glance Medicine, Ed. 4, Erlangga, Jakarta.

De Leeuw,Peter W et al, 2016, Salt and Sensitivity in Hypertension. 201. p 499-505

DewiVonny Khresna,2014,Hubungan Obesitas Dengan Kejadian Hipertensi di Puskesmas Rawat Inap Danau Panggang ,An-nadaa Jurnal Kesehatan Maasyarakat.Vol 1,no2.

Febri Endra Budi S, 2015,Buku Pembelajaran Ilmu Kedokteran Keluarga,Ed.1,Laboratorium Kedokteran Keluarga dan Industri FK UMM,Malang.

Genilda Maria ,2012,Hubungan Asupan Natrium dan Kalium dengan Tekanan Darah pada Pasien Hipertensi di Unit Rawat Jalan di Rumah Sakit Guido Valadares Dili Timor Leste,2012,Fakultas Kesehatan, Universitas Respati Yogyakarta.

Geethavani, G et al.2014,Effect of Caffeine on Heart Rate and Blood Pressure, International Journal of Scientific andResearch Publications, vol.4, no.2 hh.1-2
Ha, Sung Kyu.2014,Dietary Salt Intake and Hypertension, US National Library of Medicine national Instititute of Health, vol 12 hb. 7-18

Harrison,2000,Prinsip Prinsip Ilmu Penyakit Dalam, Ed 13,EGC, Jakarta.

Hu B, 2015, Effects of Psychological Stress on Hypertension in Middle-Aged Chinese: A Cross-Sectional Study, Shanghai Institute of Hypertension China

Hull, A. 2001,Penyakit Jantung Hipertensi dan Nutrisi,Bumi Aksara,Jakarta.

Huon H.Gray, Keith D.Dawkins, John M.Morgan, et al,2005, Kardiologi,4th edn, EMS, Jakarta.

Kevin A.Bybee, Michelle L.Dew,Stephanie L.Lawhorn, et al, 2014, Penyakit Kardiovaskular Pada Wanita,EMS, Jakarta

Kumbla D, 2016, A Study of Salt and Fat Consumption Pattern in Regional Indian Diet among Hypertensive and Dyslipidemic Patients -SCRIPT study, India, Journal of Association of Physicians India Vol. 64 pp. 47

Laurale sherwood, 2014,Fisiologi Manusia, Ed.8,EGC,Jakarta

Libri Oktavian ,2016,Hubungan Tingkat Pengetahuan dan Konsumsi Natrium Terhadap Tekanan Darah Penderita Hipertensi di Wilayah Kerja Puskesmas Cempaka Tahun 2015, Banjarbaru ,Jurnal Kesehatan Indonesia.vol 6

Lidyawati, 2014, Hubungan Asupan Asam Lemak Jenuh, Asam Lemak Tidak Jenuh Dan Natrium Dengan Kejadian Hipertensi Pada Wanita ,Menopause di Kelurahan Bojongsalaman, Strata 1 Program Studi Ilmu Gizi, Universitas Diponegoro, Semarang.

Mesas AE et al,2011. The Effect of Coffe on Blood Pressure and Cardiovascular disease in Hypertensive individuals: a systemic review and meta analysis

M.Rachmat Soelaeman, 2015, Hipertensi Pada Penyakit Ginjal, In :Siti Setiati, Idrus Alwi, Aru W Sudoyo (Eds),Buku Ajar Ilmu Penyakit Dalam, 2 Edn, Interna Publishing, Jakarta,pp 2296-2307.

Natalia Diana,Petrus Hasibuan, Hendro, 2015,Hubungan Obesitas dengan Kejadian Hipertensi di Kecamatan Sintang, Kalimantan Barat, Jurnal FK Universitas Tanjungpura vol. 42 no.5, pp336-339. 


\section{VOLUME 12 NOMOR 2 DESEMBER 2016}

Philip I.Aronson \& Jeremy P.T.Ward,2010,At A Glance Sistem Kardiovaskular, Ed.3,Erlangga, Jakarta.

Pranawa, Artaria Tjempakasari,2015, Hipertensi, In :Askandar Tjokroprawiro, Poernomo Budi Setiawan, Chairul Effendi,Buku Ajar Ilmu Penyakit Dalam Fakultas Kedokteran Universitas Airlangga Rumah Sakit Pendidikan Dr.Soetomo Surabya,Ed.2,Pusat Penerbitan dan Percetakan Unair, Surabaya.pp. 514-524

Suparto, Faktor Risiko yang Paling Berperan Terhadap Hipertensi pada Masyarakat Kecamatan Jatipuro Kabupaten Karanganyar Tahun 2010.Magister Kedokteran, Universitas Sebelas Maret, Surakarta.

Suprihatin Anggun, Raharjo Bejo, Annisa Catur,2016,Hubungan Antara Kebiasaan Merokok, Aktivitas Fisik, Riwayat Keluarga dengan Kejadian Hipertensi di Wilayah Kerja Puskesmas Nguter,Universitas Muhammadiyah Surakarta.Solo.

Yusuf Alfian,2015,Hubungan Gaya Hidup dengan Hipertensi pada Pengunjung Puskesmas Teluk Dalam Banjarmasin,Jurnal Skala Kesehatan,Vol 6,no 1.

Zhang Z,Gang Hu, Benjamin C, Lawrence A, Liwel Chen, 2011, Habitual Coffe Consumption and Risk of Hypertension : a systemic review and metaanalysis of prospective observational studies. The American Journal of Clinical Nutrition 93 :1212-1219 